\title{
Technology in healthcare: A case study of healthcare supply chain management models in a general hospital in Singapore
}

\author{
Mittal Chikul, Hsann Yin Maw, Yang Kok Soong \\ Epidemiology Unit, NTFGH, Jurong Health Services, Singapore
}

Received: October 26, 2017

Accepted: November 28, 2017 Online Published: December 1, 2017

DOI: $10.5430 /$ jha.v6n6p63

URL: https://doi.org/10.5430/jha.v6n6p63

\begin{abstract}
Objective: To simulate and compare a manual hospital supply chain management model versus a process that is technologically integrated (either by Radio Frequency Identification [RFID] technology or automated guided vehicles [AGVs]), in a general hospital in Singapore.

Methods: Design: Deterministic modelling of hospital supply chain management for manual and technologically integrated processes as part of the institutional quality improvement exercise. Setting: Study was conceptualised during re-location of a 355-bed general hospital to newer premises within Singapore with an increased capacity of 700 beds. Study duration was 1.5 years and data collection was performed from Sep 2014 to Sep 2015.

Results: Automating the inventory check and use of automated guided vehicles for medical supplies can improve business and operational performance by saving time on no-value added activities that can be transferred to patient care. RFID intervention requires least number of man-hours per day reducing the total manpower requirements by about one third as compared to the manual process while improving productivity by about $40 \%$, it also provides cost savings of about $25 \%$ over a period of 10 years. Sensitivity analysis shows that extent of these cost savings are dependent on overall staff utilisation. Although use of AGV alone is expensive in our model, combining AGVs with RFID technology provides the least manpower dependence among the different interventions studied, it also gives a positive return on investment as compared to manual process beyond 3 years of operations. Conclusions: Optimising supply chains within healthcare helps minimise manpower dependency and costs. However, prior to adopting a specific intervention, the unique characteristics of each healthcare setting should be considered. There is need for similar research into healthcare supply chains to identify key determinants to cost savings and improving productivity, both locally and regionally.
\end{abstract}

Key Words: Automated guided vehicles, Radio Frequency Identification, Singapore hospitals, Hospital logistics, Hospital supply chain management

\section{INTRODUCTION}

An increasing demand for healthcare services due to an ageing population, a move away from institutional care, an increasing shortage of doctors, nurses and skilled ancillary personnel, work pressures, ineffective communication mechanisms $^{[1,2]}$ and inappropriate resource allocations have made reducing waste in healthcare and improving its efficiency a global priority. With approximately 80 percent of expenses

\footnotetext{
${ }^{*}$ Correspondence: Mittal Chikul; Email: epidemiology@juronghealth.com.sg; Address: Epidemiology Unit, Tower A, Level 8, Ng Teng Fong General Hospital and Jurong Community Hospital, 1 Jurong East, Street 21, 609606, Singapore.
} 
tied to patient care activities, healthcare institutions can certainly obtain substantial savings while improving clinical practices by better managing labour, supplies, equipment and facilities. ${ }^{[2]}$

Among the technological solutions studied to increase healthcare efficiencies are new automation tools such as radiofrequency identification (RFID) which is emerging as the standard for hospitals and healthcare centres to track valuable and strategic mobile assets in medical facilities, identify and locate patients and staff, ${ }^{[3]}$ as well as automated guided vehicles (AGVs), which have been proven effective in transporting hospital supplies including pharmacy, food, linen, etc. to different wards, saving costs and also decreasing reliance on manpower. ${ }^{[4-9]}$

Singapore healthcare system is at par with developed health systems and is known to employ/evaluate latest technological advances in logistics to improve efficiency. It also suffers a double whammy of tight labour market as well as ageing workforce, justifying a constant need for improvement in supply chain efficiency. The decision on what technology hospitals should deploy is dependent on local factors including manpower constraints, costs, push for higher efficiency, etc. Decision to study RFID and AGVs was made at institutional level as local hospitals have been using RFIDs and/or AGVs in medical supply management for many years; however, there is paucity of local published literature on use or combination of these technologies in healthcare settings, making this study relevant for both existing and new hospitals.

We aim to simulate the supply chain models for manual and technologically integrated processes using value stream maps and deterministic modelling to compare these processes in terms of labour man hours, total costs as well as productivity in a general hospital in Singapore.

The study findings are expected to facilitate healthcare supply chain optimisation and decision making in similar or relatable economies within the region and beyond, particularly for countries facing tight labour market and ageing work force; and for those constantly on a look out to improve efficiency in hospital operations.

\section{MATERIALS AND METHODS}

\subsection{Setting}

Study was conceptualised during re-location of a 355-bed general hospital to newer premises within Singapore with an increased capacity of 700 beds. Study duration was 1.5 years and data collection was performed from Sep 2014 to Sep 2015.

Table 1. Semi-structured Interviews and on-site observations

\begin{tabular}{|c|c|c|c|}
\hline $\begin{array}{l}\text { Domain } \\
\text { Experts }\end{array}$ & $\begin{array}{l}\text { Number } \\
\text { of SSIs }\end{array}$ & $\begin{array}{l}\text { Average experience } \\
\text { (in years) }\end{array}$ & Domain Questions (Items tested in SSI) \\
\hline Manpower & 3 & 10 & $\begin{array}{l}\text { - Determinants of manpower efficiency in healthcare } \\
\text { - Ministry of manpower standards and work hours (Singapore) } \\
\text { - Industry norms for efficiency, productivity, rest time, breaks on shift }\end{array}$ \\
\hline $\begin{array}{l}\text { Medical } \\
\text { Supplies }\end{array}$ & 4 & 9 & $\begin{array}{l}\text { - Details of work process including time taken for each sub-process } \\
\text { - Experience with use of technology in medical supplies including but not } \\
\text { limited to RFID and AGV } \\
\text { - Industry norms for efficiency, productivity, rest time, breaks on shift }\end{array}$ \\
\hline RFID & 3 & 8 & $\begin{array}{l}\text { - Introduction about technology } \\
\text { - Implications to costs and manpower (based on experience, including } \\
\text { maintenance) } \\
\text { - Evidence or examples of successful application elsewhere }\end{array}$ \\
\hline AGVs & 3 & 8 & $\begin{array}{l}\text { - Introduction about technology } \\
\text { - Implications to costs and manpower (based on experience, including } \\
\text { maintenance) } \\
\text { - Evidence or examples of successful application elsewhere }\end{array}$ \\
\hline \multicolumn{4}{|c|}{ Domains tested in on-site observation form (old hospital site and simulated for new hospital site) } \\
\hline \multicolumn{4}{|c|}{$\begin{array}{l}\text { 1. Details of hospital supply chain management process (subgroups): inventory check, order generation, order picking and order } \\
\text { delivery } \\
\text { 2. Time taken to perform each task : average of } 30 \text { observations taken over } 2 \text { months } \\
\text { 3. Manpower required for each task: average of } 10 \text { observations taken over } 2 \text { months } \\
\text { 4. Risk assessment: Following the staff involved in each sub-process to document possible occupational risks and likelihood. }\end{array}$} \\
\hline
\end{tabular}


Table 2. Key assumptions for the analysis

\begin{tabular}{|c|c|c|c|}
\hline No & Assumption & Explanation & Source \\
\hline 1. & $\begin{array}{l}\text { Time for each } \\
\text { process within } \\
\text { value stream maps }\end{array}$ & $\begin{array}{l}\text { Time taken by hospital staff to complete each step during } \\
\text { manual and automated process in the proposed new hospital }\end{array}$ & $\begin{array}{l}\text { Qualitative: Subject matter experts, Vendor } \\
\text { quotes. } \\
\text { Quantitative: time motion study on existing } \\
\text { process. }\end{array}$ \\
\hline 2. & $\begin{array}{l}\text { Work hours per } \\
\text { day }\end{array}$ & $\begin{array}{l}\text { Working hours: } 08: 30 \text { a.m. to } 17: 56 \text { p.m. } \\
\text { Minus } 1 \text { hour lunch break }=8.4 \text { hours per day, } 42 \text { hours per } \\
\text { week ( } 5 \text { working days) }\end{array}$ & $\begin{array}{l}\text { Hospital Policy } \\
\text { Singapore Ministry of Manpower } \\
\text { Guidelines }\end{array}$ \\
\hline 3. & $\begin{array}{l}\text { Staff utilization } \\
\text { rate }\end{array}$ & $\begin{array}{l}\% \text { of available time the average staff spends on specific } \\
\text { assignments and tasks. } \\
\text { Working hours: } 08: 30 \text { a.m. to } 17: 56 \text { p.m., } 1 \text { hour lunch break. } \\
\text { - } 100 \%=8.4 \text { hours per day } \\
\text { - Proposed = additional } 5 \text { min per hour allotted break time } \\
\quad(40 \text { min for } 8 \text { hours); } 7.7 \text { hours per day }(92 \%) \\
\text { - } 80 \%=6.7 \text { hours per day }\end{array}$ & $\begin{array}{l}\text { Qualitative: industry standards by subject } \\
\text { matter experts. } \\
\text { (Range } 80 \%-100 \% \text { ) }\end{array}$ \\
\hline 4. & $\begin{array}{l}\text { Manpower } \\
\text { multiplication ratio }\end{array}$ & $\begin{array}{l}\text { Multiplication factor for actual manpower requirements to cater } \\
\text { for additional manpower during medical leave, annual leave, } \\
\text { staff attrition, shift work, weekends, etc. (For Budgeting) }\end{array}$ & $\begin{array}{l}\text { Qualitative: industry standards by subject } \\
\text { matter experts. } \\
\text { (Range: } 1.2 \text { to } 1.5 \text { ) }\end{array}$ \\
\hline 5. & $\begin{array}{l}\text { Salaries for } \\
\text { hospital staff }\end{array}$ & $\begin{array}{l}\text { Taken as starting at } 1,800 \text { USD per month, including } 13 \\
\text { months, plus additional 3,600 USD annual cap for } \\
\text { compensation and bonuses, } 3 \% \text { salary increment per year }\end{array}$ & $\begin{array}{l}\text { Quantitative: hospital human resource } \\
\text { department, Singapore Ministry of } \\
\text { Manpower guidelines }\end{array}$ \\
\hline 6. & AGV Costs & $\begin{array}{l}\text { 2.5 Million USD for AGVs Plus 400,000 USD for construction } \\
\text { of additional floors. } \\
\text { Total: } 2.9 \text { Million USD } \\
\text { Maintenance: } \\
426,000 \text { USD for } 5 \text { year maintenance, } 10 \% \text { increase for next } 5 \\
\text { years (assumption) }\end{array}$ & Vendor quote \\
\hline 7. & Manual Trolleys & Taken at 400 USD per trolley, replaced every 3 years & Vendor quote, industry standards. \\
\hline 8. & AGV trolleys & Taken at 4,800 USD per trolley, $20 \%$ yearly maintenance. & Vendor quote, industry standards \\
\hline 9. & $\begin{array}{l}\text { Utility Discount } \\
\text { rate }\end{array}$ & Taken at $2 \%$ per year for Singapore & {$[10]$} \\
\hline
\end{tabular}

\subsection{Study design and methods}

Deterministic Model of hospital supply chain management was created for manual and technologically integrated processes as part of operations research under the institutional quality improvement exercise.

Inputs for the model were obtained from subject matter experts [healthcare supply chain management experts within the hospital as well as other hospitals locally, also including hospital planning team, AGV and RFID vendors] by using semi-structured interviews (SSI), on-site observations, experience from previous implementations, human resources department, hospital information system as well as published literature thereby increasing the reliability. Each process was studied in detail by creating value stream maps. Details regarding SSIs and onsite observation form are summarized in Table 1.

Assumptions used in deterministic model are highlighted in Table 2. The processes were then compared in terms of labour man hours, costs and productivity over a period of 10 years. Nil patient level data was used for the purpose of this study.

\subsection{Existing process for hospital supply chain manage- ment}

Table 3 illustrates the existing process for hospital supplies management by dividing it into 4 major components: inventory checking, order generation, order picking and replenishment respectively. Process entails replenishment of consumables (clinical supplies except medicines, examples: syringes, catheters, gloves, diapers, etc.) from a centralised storage facility to the point of use or service point [Ward/clinic/operating theatres].

During the existing process, inventory checking is done manually, and involves hospital staff to inspect each service point to assess the supplies that need replenishment. The staff then returns to storage facility to generate the order as well as manually pick the respective order. The order is then transported back to the service point by the staff using manual trolleys. 
Table 3. Comparison of hospital supply chain process: Manual versus RFID and AGV

\begin{tabular}{|c|c|c|c|}
\hline $\begin{array}{l}\text { System Resource } \\
\text { Requirements }\end{array}$ & Manual & RFID & AGV \\
\hline \multicolumn{4}{|c|}{ Total service points $(9,100)$} \\
\hline \multicolumn{4}{|c|}{ Process } \\
\hline Inventory Check & Manual & $\begin{array}{l}\text { RFID enabled } 2 \text { bin } \\
\text { replenishment system }\end{array}$ & Manual \\
\hline Order Generation & $\begin{array}{l}\text { With current hospital } \\
\text { information system }\end{array}$ & $\begin{array}{l}\text { New hospital information } \\
\text { system linked to RFID }\end{array}$ & $\begin{array}{l}\text { With current hospital } \\
\text { information system }\end{array}$ \\
\hline Order Picking & Manual & Manual & Manual \\
\hline $\begin{array}{l}\text { Order Delivery } \\
\text { - Transport } \\
\text { - Replenishment }\end{array}$ & $\begin{array}{l}\text { - Manual Trolley } \\
\text { - Manual }\end{array}$ & $\begin{array}{l}\text { - Manual Trolley } \\
\text { - Manual }\end{array}$ & $\begin{array}{l}\text { - AGV, AGV trolley (+ few } \\
\text { Manual trolleys) } \\
\text { - Manual }\end{array}$ \\
\hline $\begin{array}{l}\text { Total Man-hours } \\
\text { required to serve all } \\
\text { areas/service points }\end{array}$ & 282 hours & 187 hours & 265 hours \\
\hline $\begin{array}{l}\text { Number of Staff } \\
\text { required }^{* *}\end{array}$ & 55 & 38 & 53 \\
\hline
\end{tabular}

Note. ${ }^{*}$ based on value stream maps; ${ }^{* *}$ based on deterministic modeling

\subsection{Details of interventions}

Three hospital supply chain management models were studied; in Model 1 (Manual), inventory checking, picking as well as transportation was done manually and order was generated by manually keying the data into the existing hospital information system. In Model 2 (automated inventory check) or RFID Model, inventory checking was automated using a RFID enabled 2 bin replenishment system. 2 bins for each supply were placed at each service point. Staff used supplies from one bin; once empty, the RFID tag helped signal inventory supply while staff could continue to use the other bin. Order was generated using the new information system linked to the RFID technology. ${ }^{[1-16]}$ In Model 3 (automated delivery) or AGV Model, inventory checking, picking and replenishment at service points were manual, order was generated by manually keying in the existing hospital information system while transportation was automated using AGVs. Detailed comparison of the 3 models in terms of process is depicted in Table 3. ${ }^{[17-21]}$

\subsection{Assumptions for the model}

Table 2 shows the assumptions made and the sources of assumptions for deterministic modelling. All the assumptions quoted were obtained and re-verified from subject matter experts. Only a proportion of costs of AGVs and RFID that justified department's share of the resources were used in the calculations. (These technologies are common resources shared by other hospital departments e.g. pharmacy, linen, kitchen, sterile services, etc.). Salaries for staff corresponded to the Singapore Ministry of Manpower guidelines as well as current industry practice. Work hours per day were obtained from Ministry of Manpower guidelines as well as the Institutional Policy. ${ }^{[22-24]}$

\section{RESULTS}

Table 3 summarizes the total man-hours as required by each of the three processes, RFID intervention requires least number of man-hours per day (187), resulting in savings of 95 man hours per day (33\%) between manual and RFID process. Using AGV alone also results in man-hour savings, but of a smaller magnitude as compared to RFID.

Based on man-hours, number of staff required for order generation, picking and transport is calculated; as described in Table 3 , the number of staff required decreases from 55 to 38 with RFID technology, a reduction of $>30 \%$ as compared to manual process; this is particularly significant for countries like Singapore where labour is a scarce resource.

Table 4 compares the total costs due to all the interventions over 10 years based on deterministic modelling method. RFID intervention (automated inventory check) not only saves manpower, but is also found to save approximately 4.7 million USD as compared to the manual process over a period of 10 years. Use of AGV alone (without other interventions to reduce man power) has shown to be expensive possibly due to high initial system installation costs, as well as less reduction in no-value added time as compared to the manual process.

Multifactor productivity (MFP) changes, measured as total 
daily output/total daily input (OECD Manual of measuring by $40 \%$ for RFID intervention as compared to the manual, productivity) are also presented in Table 4, MFP increased while it drops 5\% by use of AGV alone.

Table 4. Comparison of total expenditure between the manual and automated processes

\begin{tabular}{|c|c|c|c|}
\hline System Resource Requirements & Manual & RFID & AGV \\
\hline \multicolumn{4}{|l|}{ Manpower } \\
\hline - Cost of required staff (Annual salary package) & $16,501,600$ & $11,401,100$ & $15,901,600$ \\
\hline \multicolumn{4}{|l|}{ Equipment } \\
\hline - Trolleys and maintenance & 71,600 & 49,500 & 319,100 \\
\hline - AGV system + Maintenance & 0.00 & 0.00 & $1,084,100$ \\
\hline \multicolumn{4}{|l|}{ Other requirements } \\
\hline • Hospital Information system linked to RFID & 0.00 & 198,800 & 0.00 \\
\hline $\begin{array}{l}\text { - Hospital Information system linked to RFID } \\
\text { (Maintenance) }\end{array}$ & 0.00 & 151,700 & 0.00 \\
\hline TOTAL & 16.5 M USD & $11.8 \mathrm{M}$ USD & 17.2 M USD \\
\hline \multicolumn{4}{|c|}{ Service points $(9,100)$} \\
\hline $\begin{array}{l}\text { - Multi-factor Productivity }{ }^{*} \text { (MFP) [Total Daily Output/ } \\
\text { Total Daily Input] }\end{array}$ & $\begin{array}{l}-9,100 / 4,540.1 \\
\quad \text { Service points per USD }\end{array}$ & $\begin{array}{l}\text { - } 9,100 / 3,229 \\
\text { Service points per USD }\end{array}$ & $\begin{array}{l}-9,100 / 4,726.8 \\
\quad \text { Service points per USD }\end{array}$ \\
\hline $\begin{array}{l}\text { - Total output calculated as service points, while total input } \\
\text { calculated as total daily costs in USD }\end{array}$ & $\bullet=2.0$ & $\bullet=2.8$ & $\bullet=1.9$ \\
\hline Change in MFP as compared to Manual process & Baseline & $\begin{array}{l}2.8 / 2.0 \\
=+40 \%\end{array}$ & $\begin{array}{l}1.9 / 2.0 \\
=-5 \%\end{array}$ \\
\hline
\end{tabular}

Note. ${ }^{*}$ OECD Manual for measuring productivity; all prices reflected in USD

\section{Sensitivity analysis}

Institutions may choose combinations of different technologies instead of relying on just one. Also, staff utilisation rates and manpower multiplication ratios are also described as ranges by industry experts rather than point estimates.

Thus, to understand the effects of varying staff utilisation rates, manpower ratios as well as combination of technologies over 10 years, sensitivity analysis was conducted, key variables in sensitivity analysis are summarised in Table 5 .
Best case-worst case scenarios were compared for 4 different processes: manual, RFID alone, AGV alone, RFID+AGV combination.

Sensitivity analysis (see Figure 1) shows that within all the three scenarios (best case, worst case and proposed case) RFID intervention appears to be most cost saving. Combination of RFID and AGV provides least manpower dependent alternative; this might be an important consideration for economies like Singapore, with a tight labour market.

Table 5. Sensitivity analysis: Considerations and scenarios

\begin{tabular}{lc}
\hline Variables & Range considered \\
\hline - Staff Utilization Rate & $\bullet 80 \%-100 \%$ \\
- Manpower Multiplication Ratio & $\bullet 1.2-1.5$ \\
Processes Compared & Manual, AGV alone, RFID alone, AGV+RFID \\
For Sensitivity Analysis: Best case/ Worst case & scenarios were constructed. With Best case corresponding to Least manpower \\
requirements and costs; while worst case to Maximum manpower requirements and costs based on varying these 2 variables. \\
Scenarios & Variable Values \\
Best Case (Least Costs) & $100 \%$ staff utilization rate and 1.2 manpower multiplication factor \\
Worst Case (Maximum Costs) & $80 \%$ staff utilization rate and 1.5 manpower multiplication factor \\
Proposed Case & $92 \%$ staff utilization rate and 1.5 manpower multiplication factor \\
\hline
\end{tabular}

It is also noted that costs as well as manpower are dependent on overall staff utilisation rates. Costs and manpower requirements also vary significantly with manpower multiplication fraction in consideration, thus departments with lower MC rates or attrition are likely to have additional cost savings, and may be required to budget for lesser manpower.

For more objective assessment of costs, a return on invest- ment (ROI) analysis was performed for "proposed case" of sensitivity analysis keeping utility discounting at $2 \%$, and technology inflation and maintenance costs as suggested by vendors. Figure 2 shows return on investment impact over time as compared to manual process, AGV+RFID option gives a positive ROI when compared to manual process beyond 3 years. 
Comparison of Cumulative 10 year costs based on assumptions: Best CaseWorst Case

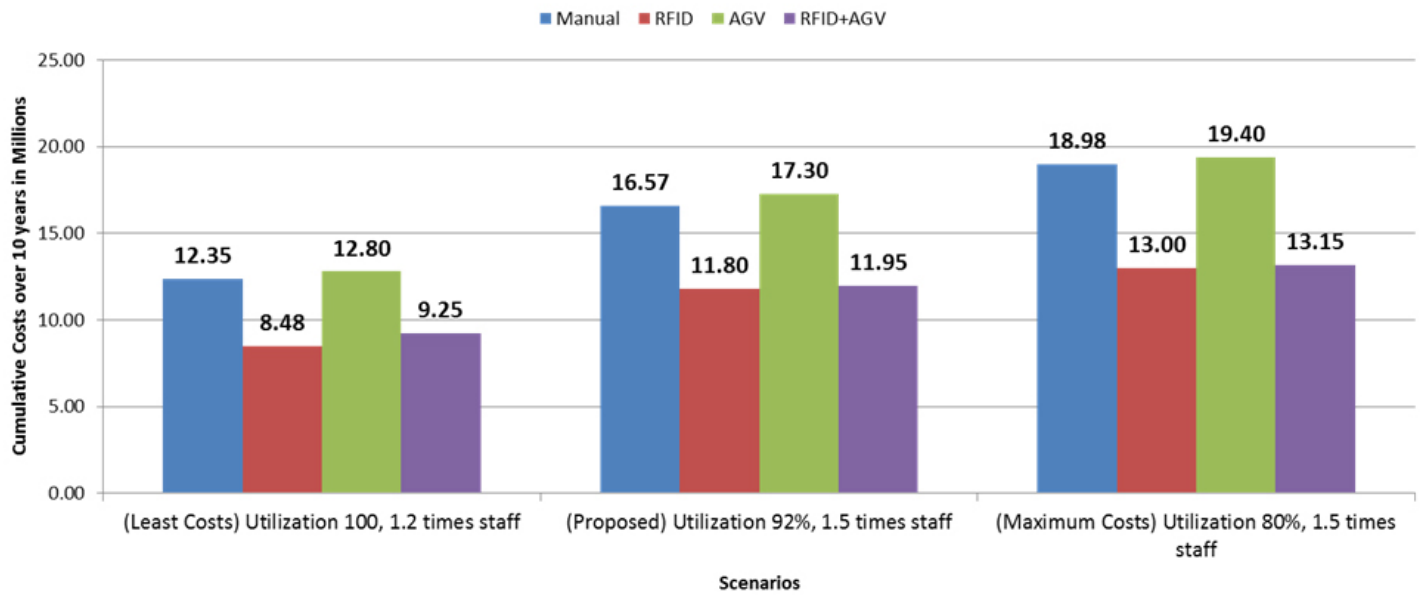

\begin{tabular}{c|c|c|c}
\hline Model & $\begin{array}{c}\text { Total Amount } \\
(10 \text { years })\end{array}$ & $\begin{array}{c}\text { Range* in Million USD } \\
\text { Manpower Requirement (Range) }\end{array}$ \\
\hline Manual & $\$ 16.5 \mathrm{M}$ & $12.3 \mathrm{M}-18.9 \mathrm{M}$ & $55(41-63)$ \\
\hline $\begin{array}{c}\text { RFID } \\
\text { (automated inventory check) }\end{array}$ & $\$ 11.8 \mathrm{M}(-4.7 \mathrm{M})$ & $8.5 \mathrm{M}-13.0 \mathrm{M}$ & $38(27-42)$ \\
\hline $\begin{array}{c}\text { AGV } \\
\text { (Automated Transport/Delivery) }\end{array}$ & $\$ 17.3 \mathrm{M}(+0.8 \mathrm{M})$ & $12.8 \mathrm{M}-19.4 \mathrm{M}$ & $53(38-60)$ \\
\hline RFID+AGV & $\$ 11.9 \mathrm{M}(-4.6 \mathrm{M})$ & $9.2 \mathrm{M}-13.1 \mathrm{M}$ & $34(25-38)$ \\
\hline
\end{tabular}

*Range: Based on Best Case- Worst Case Scenario; all prices in USD

Figure 1. Sensitivity analysis, best case-worst case scenarios

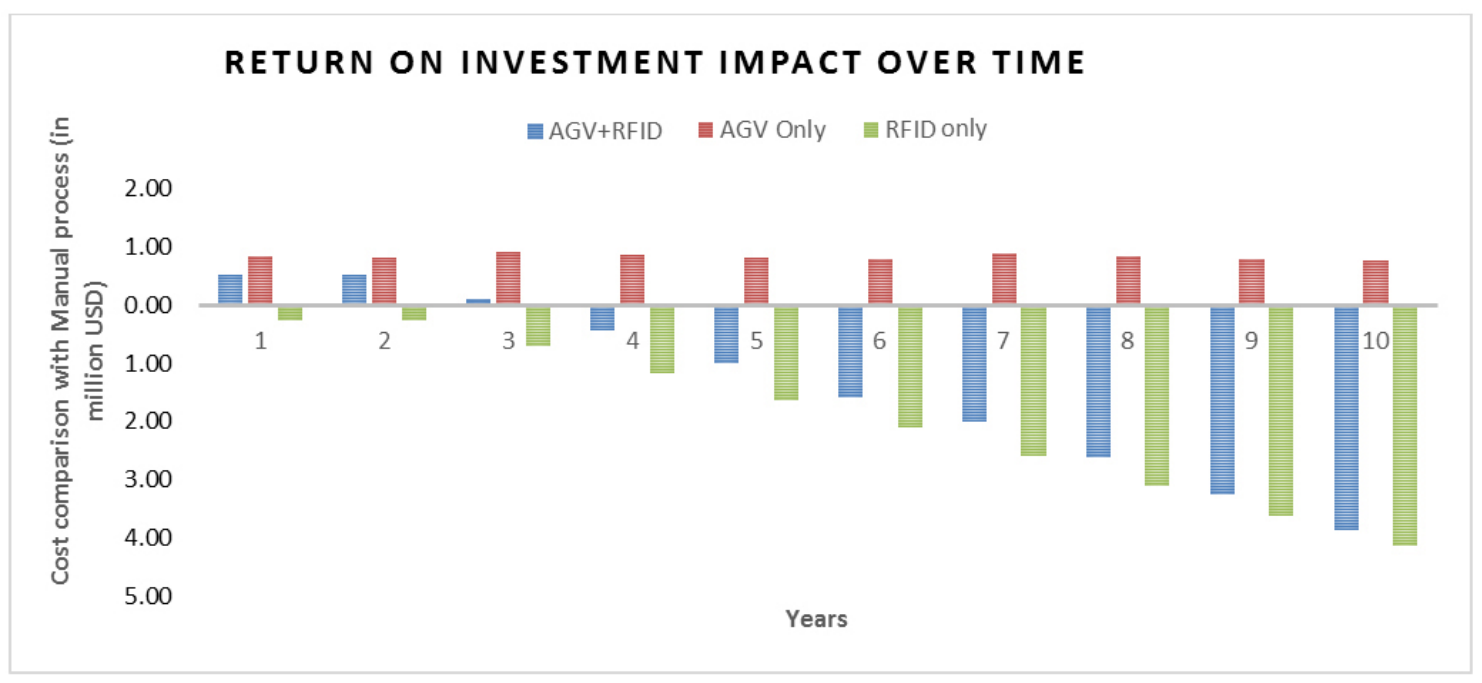

Figure 2. Return on investment analysis over time

\section{Discussion}

The analysis provides a level ground for comparison of contemporary technologies for management of hospital supplies both locally as well as regionally, with each having unique individual benefits. Sensitivity analysis (see Figure 1) shows that although RFID technology results in significant savings, both in man hours as well as direct costs, the extent of savings are dependent on overall staff utilisation, e.g. departments with lesser workload might not be able to generate sufficient staff utilisation to maximize profits. 
One of the ways to overcome this situation is to integrate staff of different departments (e.g. linen, consumables, kitchen, pharmacy, etc.) handling supplies to service points under one supervisory framework. This will maximize staff utilisation and in turn result in cost savings by allowing cross cover or shift patterns. Hospitals may even decide to outsource this replenishment component of the supply chain, as outsourcing will help preserve the ratio of local: foreign staff for core hospital operations (e.g. nursing), also it will transfer the liability of staff utilization to maximize profit margins to the external vendor. The details of these considerations are however beyond the scope of this study.

AGVs simply speaking are electronic trolleys that automate the transport process, so the medical supplies reach from storage to "point of utilization" requiring minimal human effort. Previous industry studies ${ }^{[25]}$ suggest that AGVs offer ergonomic benefits to the workforce by reducing the distance travelled with load (trolley). This provides intangible long term benefits like possibility to accommodate ageing workforce, better outcomes like decreased workplace injuries, staff turn-over, medical leave rates, etc. ${ }^{[26,27]}$ Formal published research evidence in healthcare setting for this is however scarce, these can be explored in a separate study. They can be timed to precision, increasing predictability of medical supplies which is imperative for hospital operations, and can also be optimized to carry multiple department's supplies simultaneously thus improving productivity. ${ }^{[2,24]}$ All these must be considered before comparing AGV costs with manual and other interventions.

The decision as to which technology should be adopted depends on various contextual constraints. While RFID intervention provides clear benefits both in terms of cost savings as well as decreased dependence of manpower, combining AGVs with RFID technology provides least dependence on manpower and also automates the process at marginally higher price as compared to using RFID alone.

\section{Conclusions}

In our study, adoption of the RFID enabled 2 bin replenishment system for medical supplies not only improves efficiency by tracking usage and ensuring availability; it also results in significant cost savings (4.7 million USD over 10 years) and decreased manpower dependence (by $>30 \%$ ) as compared to the manual process. Augmenting the manual system with a combination of RFID and AGVs further improves the manpower savings and also adds ergonomic and automated delivery benefits of AGVs at comparable costs.
Although requiring an initial investment, combination of RFID and AGV yields a positive ROI as early as beyond 3 years.

Thus, authors note that healthcare supply chain optimization using RFID with or without AGV system is reliable and costeffective in comparable health systems facing tight labour market and ageing workforce.

Healthcare is a complex system and healthcare administrators are often faced with tight budgets. Justification for technology adoption should be brisk, well debated, well studied and widely shared to allow rapid up-scaling of best practices. Optimising supply chains within healthcare settings helps minimize manpower dependency and costs. However, prior to adopting a specific intervention, the unique characteristics of the healthcare setting should be considered.

This study emphasises on the need for similar operational research into healthcare supply chains to identify key determinants to cost saving and improving efficiency, both locally and regionally.

\section{Limitations}

Case study approach, with generalizability only to relatable healthcare settings.

Deterministic model is highly dependent on the assumptions made for the calculations, and potential cost and manpower savings can change significantly on changing the assumptions. Authors have attempted sensitivity analysis to provide a possible range based on varying key variables to minimize this.

The study involves consideration of clinical supplies from just one department, for more accurate projections, all related departments using concerned technology (e.g. AGVs could be used by kitchen, materials management, linen, pharmacy, etc.) must be modelled and studied simultaneously. This could have resulted in lower estimates of productivity gains by AGVs.

\section{ACKNOWLEDGEMENTS}

We are grateful for the support from departments of Innovations \& Improvement, Epidemiology, COOs office and Material Management (MND) for their kind inputs and suggestions. We are also grateful to Mr Lim Meng Keong for his expert opinion and help in creating value stream maps.

\section{CONFLiCTS OF INTEREST Disclosure}

The authors declare they have no conflicts of interest. 


\section{REFERENCES}

[1] Ross SM. Introduction to Probability Models. Ninth Edition. California: University of California Berkeley; 2007. Available from: http: //www . endustri.anadolu.edu.tr/c_aghayeva/\%C4\%BOST\% 20411 /duyuru/Introduction $\% 20$ to $\% 20$ Probability $\% 20$ Mod els $\% 20$ (Sheldon $\% 20$ M. Ross $\% 20, \% 209$ th $\% 20$ Edition).pdf

[2] Innovation in medical technologies. UK Focus International Meeting. London: The Royal Academy of Engineering; 2013. Available from: http://www.raeng.org.uk/publications/repo rts/nov-13-innovation-in-medical-technologies

[3] Kumar A, Ozdamar L. Business process reengineering at the hospitals: a case study at Singapore hospital. Proceeding of the 18th European Simulation Multi Conference. Magdeburg, Germany; 2004. 308-17 p.

[4] Fisher JA, Monahan T. Tracking the social dimensions of RFID systems in hospitals. International Journal of Medical Informatics. 2008; 77(3): 176-83. PMid: 17544841. https://doi.org/10.1016/j ijmedinf . 2007.04.010

[5] Bendavid Y, Lefebvre E, Lefebvre LA, et al. Key performance indicators for the evaluation of RFID-enabled B-to-B e-commerce applications: the case of a five-layer supply chain. Information Systems and E-Business Management. 2009; 7(1): 1-20. https: //doi.org/10.1007/s10257-008-0092-2

[6] Tzeng SF, Chen WH, Pai FY. Evaluating the business value of RFID evidence from five case studies. International Journal of Production Economics. 2008; 112(2): 601-13. https://doi.org/10.1016/ j.ijpe.2007.05.009

[7] Bottani E, Rizzi A. Economical assessment of the impact of RFID technology and EPC system on the fast-moving consumer goods supply chain. International Journal of Production Economics. 2008; 112(2): 548-69. https://doi.org/10.1016/j.ijpe.2007.05 .007

[8] Chaudhry B, Wang J, Wu S, et al. Systematic review: impact of health information technology on quality, efficiency, and costs of medical care. Annals of Internal Medicine. 2006; 144(10): 742-52. PMid: 16702590. https://doi.org/10.7326/0003-4819-144 -10-200605160-00125

[9] Wicks AM, Visich JK, Li S. Radio frequency identification applications in healthcare. International Journal of Healthcare Technology and Management. 2006; 7(6): 522-40. https : //doi .org/10.150 4/I JHTM. 2006. 010414

[10] Zhuang JZ, Liang ZH, Lin T, et al. Theory and Practice in the choice of social discount rate for cost-benefit analysis: A Survey. ERD Working Paper Series No. 94. Asian Development Bank. 2007. Available from: http://www.adb.org/sites/default/files/ publication/28360/wp094.pdf

[11] Curtin J, Kauffman RJ, Riggins FJ. Making the most out of RFID technology: a research agenda for the study of the adoption, usage and impact of RFID. Information Technology and Management. 2007; 8(2): 87-110. https://doi.org/10.1007/s10799-007 -0010-1

[12] Delen D, Hardgrave BC, Sharda R. RFID for better supply chain management through enhanced information visibility. Production and Operations Management. 2007; 16(5): 613-24. https://doi.org/ 10.1111/j.1937-5956.2007.tb00284.x

[13] Heese HS. Inventory inaccuracy, double marginalization, and RFID adoption. Production and Operations Management. 2007; 16(5): 542
53. https://doi.org/10.1111/j.1937-5956.2007.tb00279 . $\mathrm{x}$

[14] Ngai EWT, Moon KL, Riggins FJ, et al. RFID research: an academic literature review (1995-2005) and future research directions. International Journal of Production Economics. 2008; 112(2): 510-20. https://doi.org/10.1016/j.ijpe.2007.05.004

[15] (The) American Hospital association Report. Hospitals Demonstrate Commitment to Quality Improvement. 2012. Available from: http://www . aha.org/research/reports/tw/12oct-t w-quality.pdf

[16] Wang SW, Chen WH, Ong CS, et al. RFID applications in hospitals: a case study on a demonstration RFID project in a Taiwan hospital. Proceedings of the 39th Hawaii International Conference on System Sciences (HICSS'08). Kauai, HI; 2006. https : //doi.org/10.1109/HICSS. 2006.422

[17] Xiong Z, Pokharel S. Logistics in hospitals: a case study of some Singapore hospitals. Leadership in Health Services. 2007; 20(3): 195-207. https : //doi .org/10.1108/17511870710764041

[18] Co GC, Tanchoco JMA. A review of research on AGVS vehicle management. Engineering Costs and Production Economics. 1991; 21(1): 35-42. https : //doi .org/10 . 1016/0167-188X (91) 90016-U

[19] Le-Anh T, De Koster MBM. A review of design and control of automated guided vehicle systems. European Journal of Operational Research. 2006; 171: 1-23. https://doi.org/10.1016/j.ejor .2005 .01 .036

[20] Yuthas K, Young TS. Material matters: Assessing the effectiveness of materials management IS. Information \& Management. 1998; 33: 115-124. https ://doi.org/10.1016/S0378-7206(97)0 0028-1

[21] Dobrzykowski D, Deilami VS, Hong P, et al. Structured analysis of operations and supply chain management research in healthcare (1982-2011). Int. J. Production Economics. 2014; 147: 514-530. https://doi.org/10.1016/j.ijpe.2013.04.055

[22] Lahtinen K, Rasa PL. Safety of automated guided vehicles. A case study in a storage area. Scand J Work Environ Health. 1988; 14(suppl 1): 100-102. PMid: 3393859.

[23] Su SI, Gammelgaard B, Yang S. Logistics innovation process revisited: insights from a hospital case study. International Journal of Physical Distribution \& Logistics Management. 2011; 41(41): 577-600.

[24] CericSource V. Simulation Study of an Automated Guided-Vehicle System in a Yugoslav Hospital. The Journal of the Operational Research Society. 1990; 41(4): 299-31. https://doi.org/10.105 7 /jors. 1990.51

[25] AGVS Industry Group Spring 2011 Quarterly Report. AGVs Improve Workplace Ergonomics. Assessed May 2016. Available from: http://www.mhi.org/media/news/10656

[26] Hwang H, Moon S, Gen M. An Integrated model for the design of end-of-aisle order picking system and the determination of unit load sizes of AGVs. Computers \& Industrial Engineering. 2002; 42: 249258. https://doi.org/10.1016/S0360-8352(02)00058-X

[27] Cantley LF, Taiwo OA, Galusha D, et al. Effect of systematic ergonomic hazard identification and control implementation on musculoskeletal disorder and injury risk. Scand J Work Environ Health. 2014; 40(1): 57-65. PMid: 24142048. https://doi.org/10.527 $1 /$ sjweh. 3394 